\title{
PENERAPAN METODE ARSITEKTUR NARATIF SEBAGAI STRATEGI BERADAPTASI BERHUNI DI MASA DEPAN DI DESA SINGOSARI
}

\author{
Vania Veeska ${ }^{1)}$, Agustinus Sutanto $^{2)}$ \\ 1)Program Studi S1 Arsitektur, Fakultas Teknik, Universitas Tarumanagara, vaniavalen6@gmail.com \\ 2) Program Studi S1 Arsitektur, Fakultas Teknik, Universitas Tarumanagara, berpikirteoripraksis@gmail.com
}

\begin{abstract}
Abstrak
Tanpa kita sadari saat ini dunia tengah mengalami perubahan besar-besaran, dari satu peradaban ke peradaban berikutnya yang kita sebut sebagai shifting. Suatu perpindahan yang dapat menentukan apakah kita dapat bertahan atau tidak, berubah atau punah. Berkaitan dengan fenomena ini kita juga sudah menyaksikan urban bias, yaitu keadaan dimana urbanisasi kaum muda desa ke kota besar tidak terelakkan ketika kota dianggap menyediakan harapan lebih dan kesempatan kerja. Akibatnya? Desa semakin kekurangan kaum muda. Proyek "Rise of Rural: Incubator for Innovation" membayangkan kembali kaum muda di Desa Singosari sebagai inkubator desa karena kota sudah kehilangan kekuatannya untuk memberikan kehidupan yang lebih baik bagi masyarakat. Desa yang selalu di nomor duakan kini menjadi aktor utama perubahan dan inovasi yang terus learn, unlearn, dan re-learn untuk beradaptasi melalui pola transformasi (inkubator) berbasis pola pikir lokal dan digital (disesuaikan, tidak melulu mengacu pada revolusi 4.0). Melalui pendekatan arsitektur naratif yang terinspirasi dari nilai-nilai di dalam cerita doraemon, bagaimana Nobita dan kawan-kawan saling belajar dan berkolaborasi melalui gadget (teknologi) dari Doraemon. Menggunakan drawing as hypothesis-menampilkan beberapa gambar sebagai mimpi dan ide desain- sebagai alat komunikasi dalam penyusunan ide, konsep, menuju gambar kerja. Dari berbagai macam ide desain kemudian di kristalisasi menjadi 4 zona utama, yang di dalam ke-empat zona tersebut terdapat program pendukung aktivitas yang bersangkutan.
\end{abstract}

Kata kunci: desa; kaum muda; kolaborasi; perubahan; teknologi

\begin{abstract}
Without realizing it, the world is currently undergoing massive shifts, from one civilization to the next which we call shifting. A movement that can determine whether we can survive or not, change or become extinct. Linked with this phenomenon we have also seen urban bias, which is a situation where urbanization of rural youth to big cities is inevitable when cities are considered to provide more hope and job opportunities. As a result? Villages are increasingly short of young people. "Rise of Rural: Incubator for Innovation" is a project re-imagines the youth of Singosari Village as incubators because the city has lost its power to provide a better life for the community. The village, which is always in second place, is now the main agent of change and innovation that continues to learn, unlearn, and re-learn to adapt through transformation patterns (incubators) based on local and digital mindsets (adjusted, not only referring to revolution 4.0). Through narrative as architectural methodology which is inspired by the values in Doraemon's story. How Nobita-together with his friends-embarks for a journey, during the journey they learn from each other and collaborate through Doraemons' gadgets (technology). Using drawing as hypothesis, as a communication tool in composing ideas, concepts, towards design developments phase. From various kinds of design ideas then narrowed-down into 4 main zones, in which the 4 zones have programs to support the activities.
\end{abstract}

Keywords: collaboration; rural; shifting; technology; youth 


\section{PENDAHULUAN}

\section{Latar Belakang}

Tahun demi tahun berlalu, dunia berubah diawali oleh suatu revolusi yang menyebabkan perluasan perubahan pada setiap negara. Hal yang sama juga dirasakan di Indonesia, kota-kota berkembang pesat dan manusia berusaha menyamakan frekuensi dengan perubahan tersebut. Seluruh berita, media komunikasi, pekerjaan, perekonomian, edukasi, dan sebagainya tak terasa benar-benar menjadi kota-sentris. Saya mengambil contoh Jakarta, siapa yang tidak tahu Jakarta? Saya adalah satu dari lebih dari jutaan orang yang tinggal di Jakarta. Setiap tahun semakin banyak orang bermigrasi ke Jakarta seolah terbuai dengan berbagai kesempatan kerja dan kemewahan yang ditawarkan oleh-nya.

Mungkin beberapa dari kita telah mendengar hal ini tetapi nyatanya masalah ini belum sepenuhnya 'menyita' perhatian kita, padahal di era digitalisasi dimana sumber informasi mudah untuk didapat. Masalah ini seolah terkubur dengan berita yang jauh lebih viral dan hangat mengenai pandemi, politik, ekonomi yang semuanya berputar di kota. Sebenarnya masalah ini sudah diberitakan sejak 2016 (sebenarnya masalah ini sudah 'terbaca' dari laporan BPS/Badan Pusat Statistik di tahun 2013 artinya pemberitaan telat 3 tahun).

Seolah terbalik dari gemerlap kota, perkembangan Desa tetap berada di fase stagnan. Terlepas dari kesempatan pekerjaan yang tinggi di Jakarta, salah satu Kabupaten yang terkenal sebagai penghasil susu menghadapi masalah regenerasi petani. Anak-anak petani sering kali merantau ke kota untuk mendapatkan upah yang lebih tinggi atau murid-murid di sekolah pertanian didorong untuk mencari peluang di tempat lain karena tidak melihat ada masa depan dalam usaha peternakan orang tuanya. Bagaimana masa depan desa jika sumber daya manusia semakin sedikit, padahal sumber daya alam (potensi) begitu melimpah?

Menurut Prof. Rhenald Kasali, Indonesia justru berpaling ke desa semenjak adanya UndangUndang Desa pada 2014. Pemerintah Indonesia justru memfokuskan perhatiannya kepada desa. Hal ini selaras dengan penelitian terbaru yang sedang dijalankan oleh Rem Koolhaas karena ketertarikannya pada transformasi pedesaan, seperti sebuah desa di Swiss, Engadin dimana ia melihat populasi desa, namun desa ini berkembang (jumlah rumah liburan yang semakin meningkat dan demografi baru). la berpendapat ketika semua berkonsentrasi pada kota, revolusi berikutnya terus maju di pedalaman (Rem Koolhas, 2020).

Pentingnya kaum muda kembali ke desa sekaligus memberdayakan kaum muda yang masih ada di desa untuk learn, unlearn, dan relearn melalui program inkubator. Hal ini dilakukan agar dapat memendekkan 'jarak' dari segi kemampuan kaum muda desa, sekaligus mempersiapkan skenario di masa depan dimana mereka yang akan hidup. Desa perlu melakukan re-branding terhadap dirinya melalui sumber daya manusianya, dengan menciptakan suatu ekosistem yang dapat membentuk komunitas untuk bersama-sama berkolaborasi dan belajar menggunakan teknologi modern. Seperti halnya ketika kementrian pertanian memberikan subsidi dengan alsintan (mesin pertanian modern dalam rangka mendukung pembangunan pertanian) yang meningkatkan produktivitas tenaga kerja pertanian (dari tahun 2014-2018 mengalami kenaikan 20,35\%) untuk mendukung pertanian cerdas di Indonesia. Penerapan teknologi terbukti efektif dan mendorong produktivitas petani, bagaimana jika petani saat ini bukan hanya sebagai pengguna dari teknologi yang ada tetapi dapat menjadi salah satu orang yang dapat berkontribusi untuk menciptakan teknologi lainnya? Seperti cerita Doraemon yang menampilkan bagaimana alat-alat ajaib dapat keluar dari sebuah kantong, bahkan alat tersebut membantu kehidupan Nobita dan temantemannya. Namun sepanjang perjalanan Nobita sada bahwa menggunakan alat tidaklah cukup, la dan teman-temannya perlu berusaha untuk bersama-sama belajar, berkembang, dan berinovasi. 


\section{Rumusan Permasalahan}

Bedasarkan latar belakang yang telah dipaparkan, sehingga dapat dirumuskan beberapa masalah yang didapat, antara lain: konsep berhuni di masa depan seperti apa yang dapat memberdayakan potensi SDA (sumber daya alam) dan SDM (sumber daya manusia) di Desa Singosari, bagaimana metode narasi dapat berperan dalam desain bagunan, dan bentuk program apa saja yang diperlukan untuk memberdayakan dan mengakselerasi SDM di Desa Singosari.

\section{Tujuan}

Jika berbicara mengenai suatu proses desain maka terdapat tujuan yang hendak dicapai dari proyek ini dalam rangka persiapan untuk di masa mendatang, antara lain: mempersiapkan SDM di Desa Singosari, terutama kaum muda, sehingga siap menghadapi tantangan dan beradaptasi di masa depan. Menjadi salah satu tempat belajar berbasis skill dan manajemen talenta yang ada di desa. Memberikan program yang dapat memberdayakan kaum muda di Desa Singosari dan menciptakan 'ekosistem' yang berkelanjutan.

\section{KAJIAN LITERATUR}

\section{Dwelling}

"The word 'dwelling' means something more than having a roof over our head and a certain number of square feet. It means to meet outher for exchange of products, ideas, and feelings; it means to come to an agreement with others; it means to be oneself, having a small chosen world of our own."

(Christian Norberg-Schulz, 1984)

Hal yang serupa juga dikatakan Martin Heidegger mengenai dwelling sebagai sebuah konsep menghuni atau dasein. Hunian pada awalnya tidak merujuk pada tinggal di suatu tempat tetapi berlama-lama di jalan, dengan keraguan ke mana harus melangkah pergi. Secara filosofis, dwelling memberikan makna untuk bertahan hidup tidak cukup dengan berdiam diri/menetap, tapi harus mengembara. Maka dwelling sebagai konsep menghuni berkaitan dengan menetap dan berkelana karena sejatinya manusia akan belajar mengenai konsep menghuni itu sendiri. Elemen manusia dari kata dwelling yang berubah-ubah/dinamis mengakibatkan definisi $d$ welling yang juga lebih dinamis.

Dari definisi-definisi tersebut dapat terlihat bahwa dwelling dialami pada sakala yang lebih luas dan $d$ welling memiliki satu hal yang sama, yaitu interaksi. Untuk menjelaskan perbedaan ruang dalam mewadahi interaksi tersebut, terdapat 4 jenis dwelling yaitu natural, collective, public, dan private dwelling. Natural dwelling terjadi ketika menetap merupakan suatu tujuan, pada titik ini manusia berhenti berkelana. Collective dwelling terjadi di dalam natural dwelling yang dihasilkan, di dalam collective dwelling terdapat interaksi antar manusia dalam ruang urban. Public dwelling terjadi pada saat nilai-nilai dalam ruang urban dijaga bersama-sama yang mencakup institusi politik, sosial, dan kultural. Sedangkan private dwelling terjadi di dalam rumah dan mentransformasi rumah menjadi home. Private dwelling tidak mengapaikan kepentingan sosial dalam kehidupannya dengan komunitas, tapi menekankan dwelling sebagai pengalaman subjektif (King, 2004).

\section{Urbanisasi dan De-urbanisasi}

Bedasarkan data Badan Pusat Statistik Indonesia (BPS) pada tahun 2010, tingkat urbanisasi di Indonesia mencapai 49,8\% dan pada tahun 2015 sudah lebih dari 53,3\% penduduk Indonesia tinggal di perkotaan. Pada tahun 2025 mendatang, dari jumlah total penduduk Indonesia sebesar 273 juta jiwa, diperkirakan sekitar $68 \%$ akan bermukim di perkotaan. Hal ini bisa menjadi pisau bermata dua jika dibiarkan terus-menerus. Peningkatan diatas tidak hanya 
sekadar angka, peningkatan tersebut menandakan pertumbuhan ekonomi kota yang semakin pesat, namun sebagian besar kehidupan akan bergantung pada kota. Akibatnya desa menjadi kosong karena adanya peningkatan urbanisasi. Pandangan yang kontras ini memperlakukan kota sebagai suatu keharusan, kebaharuan, kemajuan, dan masa depan. Sementara desa sebagai ketertinggalan, kemunduran, keterbelakangan, dan masa lalu. Padahal masa depan yang sebenarnya bukan hanya di kota, melainkan juga di desa.

Jika sebelumnya orang ramai-ramai ke kota karena ekonomi berpusat di kota, kini pandemic memutarbalikan keadaan. Masyarakat beramai-ramai kembali ke kampung halaman mereka untuk menghindari dampak resesi ekonomi dan pemutusan hubungan kerja pada pekerja di kota. Fenomena ini disebut dengan de-urbanisasi, desa yang dahulu dijadikan pilihan kedua kini dianggap memiliki daya serap tenaga kerja yang lebih baik daripada kota. Bisa jadi hal ini dapat mendorong terjadinya keseimbangan baru terutama dalam hubungan ekonomi kota dan desa. Ketika para individu yang melakukan deurbanisasi tetap tinggal di desa, maka beban kota dalam menanggung ledakan jumlah migran menjadi semakin ringan dan dapat teratasi.

\section{Desa}

Sifat dan karakteristik desa secara umum dapat dilihat dari keadaan alam dan lingkungan hidupnya. Karakteristik desa selalu kontras dengan pemahaman masyarakat kota, seperti yang dikatakan Ferdinand Tonnies tentang memiliki karakteristik antara desa dan kota. Untuk lebih memahami karakteristik desa berikut adalah tabel perbandingan karakteristik antara desa dan kota:

Tabel 1. Perbandingan Karakteristik Desa dan Kota menurut Paul B. Horton \& Chester L. Hunt

\begin{tabular}{|c|c|c|}
\hline \multicolumn{2}{|r|}{ Karakteristik Desa } & Karakteristik Kota \\
\hline 1. & $\begin{array}{lr}\text { Penduduknya } & \text { cenderung } \\
\text { terisolasi dan pola } \\
\text { pemukimannya berpencar } \\
\text { (meskipun mulai mengalami } \\
\text { perubahan seiring adanya } \\
\text { revolusi desa). }\end{array}$ & $\begin{array}{l}\text { 1. Institusi pemerintah formal yang } \\
\text { berdasarkan pada batas wilayah } \\
\text { bukan kekeluargaan. } \\
\text { 2. Adanya pembagian kerja ke } \\
\text { dalam beberapa sektor dan } \\
\text { bidang khusus. }\end{array}$ \\
\hline 2. & $\begin{array}{l}\text { Ekonomi keluarga bersifat } \\
\text { subsistem, meskipun sudah } \\
\text { mulai komersial (ditandai } \\
\text { dengan munculnya } \\
\text { agribisnis/pertanian berskala } \\
\text { besar). }\end{array}$ & $\begin{array}{l}\text { 3. Teknologi rasional yang } \\
\text { berkembang seiring dengan } \\
\text { pertumbuhan kota-kota kecil } \\
\text { yang terbuka terhadap daerah } \\
\text { lain. } \\
\text { 4. Organisasi sosial yang }\end{array}$ \\
\hline & $\begin{array}{l}\text { Homogenitas dalam etnis, } \\
\text { budaya, dan pekerjaan (rata- } \\
\text { rata sebagai petani, peternak, } \\
\text { dan sebagainya). }\end{array}$ & $\begin{array}{l}\text { berdasarkan bidang pekerjaan } \\
\text { dan kelas sosial, bukan pada } \\
\text { sistem kekerabatan. } \\
\text { 5. Sistem perdagangan dan dunia }\end{array}$ \\
\hline 4. & $\begin{array}{l}\text { Hubungan dan cara pandang } \\
\text { terhadap orang lain sebagai } \\
\text { pribadi utuh, bukan sekadar } \\
\text { seseorang yang mempunyai } \\
\text { fungsi tertentu. }\end{array}$ & \\
\hline 5. & $\begin{array}{l}\text { Adat dan kebiasaan muncul } \\
\text { karena kebutuhan sosial. }\end{array}$ & \\
\hline
\end{tabular}

Sumber: Sosiologi Pedesaan, 2015 


\section{Inkubator}

Inkubator adalah suatu program dimana di dalamnya terjadi suatu proses pemberdayaan (empowering), pendampingan (mentoring), pengembangan (developing), dan kolaborasi (networking \& collaboration) dalam upaya membantu tumbuhnya suatu usaha berbasis teknologi yang sustainable. Inkubator sendiri berasal dari berbagai sektor dengan tujuan membuat sebuah program untuk pengusaha pemula dan khusus didesain membina perusahaan untuk mempercepat pengembangan usahanya. Program ini pertama kali diperkenalkan pada tahun 1959 ketika Joseph L. Manusco membuka sebuah pusat industry di New York, gedung yang awalnya digunakan sebagai tempat inkubasi ayam kemudian menjadi tempat merintis sebuah usaha pemula yang saat ini kita kenal dengan sebutan start up.

Start up adalah perusahaan di fase awal yang masih dalam pengembangan atau penelitian untuk terus menemukan pasar maupun mengembangkan produknya, istilah start up pada umumnya mengacu pada perusahaan yang layanan/produknya berbasis teknologi. Bedasarkan start up report 2019, Indonesia sendiri memiliki 6 start up Unicorn (perusahaan yang memiliki valuasi diatas 1 miliar USD) yaitu: Gojek, Tokopedia, Traveloka, Bukalapak, Ovo, dan JD.id.

Inkubator sendiri sejalan dengan paradigma baru di era globalisasi yaitu innovation and technology-based economy dimana inovasi berbasis teknoologi menjadi salah satu faktor penting dalam peningkatan kualitas hidup suatu bangsa. Maka tak heran jika buah hasil program inkubator dapat menghasilkan start up buatan anak bangsa yang mampu bersaing di kancah internasional.

\section{Jenis Inkubator}

Pada prinsipnya aktivitas yang dilakukan dalam program inkubator memiliki proses yang mirip, namun inkubator dapat dibagi dalam beberapa jenis yaitu:

a. Industrial incubator

Inkubator yang didukung oleh pemerintah dan lembaga non-profit, bertujuan untuk penciptaan lapangan kerja yang dapat mengatasi tingkat pengangguran.

b. University-related incubator

Inkubator yang bertujuan untuk melakukan komersialisasi sains, teknologi, dan HAKI dari hasil penelitian. Tipe inkubator ini menawarkan start up untuk memperoleh layanan laboratorium, computer, perpustakaan, dan jasa perguruan tinggi.

\section{c. Corporate-venture incubator}

Inkubator yang di dirikan oleh perusahaan yang sudah mapan untuk mengakusisi perusahaan kecil, lalu memberikan suntikan dana ke perusahaan kecil tersebut.

Dari ketiga jenis inkubator yang telah dijelaskan, proyek ini mengarah ke jenis inkubator yang pertama dengan tujuan penciptaan lapangan kerja sekaligus mendukung peningkatan keterampilan bagi SDM, diharapkan dengan adanya program ini akan tercipta rantai lapangan kerja (job creation) yang mempunyai nilai tambah (added value). Rangkaian proses ini mampu menimbulkan inovasi berdampak positif pada komersialisasi teknologi yang mampu mendorong penciptaan dan peningkatan kesejahteraan masyarakat. Hal ini tentu mempunyai korelasi dengan narasi yang dipilih oleh penulis, salah satunya dalam hal proses pemberdayaan melalui beberapa program yang berbasis teknologi.

\section{METODE}

\section{Arsitektur Naratif}

Metode perancangan yang digunakan, dalam eksplorasi ide, konsep, dan mencari isu terkait hingga menghubungkannya dengan desain, adalah arsitektur naratif. Meminjam narasi/cerita untuk mengolah narasi menjadi ruang. Pendekatan naratif merupakan salah satu metode 
untuk mengevaluasi cerita dari suatu tempat mulai dari menyusun konsep, proses desain, dan sebagai alat komunikasi (Sophia Psarra, 2009). Kemudian F. E. Tssink dalam bukunya yang berjudul Narrative-drive Design juga membahas bahwa narasi adalah interaksi ganda yang di analogikan seperti seorang arsitek dan pengguna, maka disinilah terjadi irisan antara arsitektur dan naratif. Untuk mengetahui lebih dalam bagaimana peran naratif dalam arsitektur, Tssink membagi peran tersebut kedalam 3 poin sebagai berikut:

\section{a. Linking/ hubungan}

Menghubungkan lingkungan dan indentitas. Melalui narasi, cerita, kejadian dan memori, seseorang bisa merasakan koneksi terhadap lingkungan yang membentuk sebuah identitas.

b. Structuring/kerangka

Arsitektur naratif juga memiliki peran menambahkan kerangka cerita terhadap sebuah pengalaman ruang. Dengan menambahkan kerangka cerita maka arsitek dapat menentukan program, kebutuhan ruang, serta bentuk fisik suatu bangunan yang menyesuaikan proses dan pengalam ruang bedasarkan alur cerita.

\section{c. Framing}

Pembingkaian dalam sebuah narasi arsitektur dapat membantu seorang arsitek untuk memanipulasi persepsi seseorang dalam arti membuat seorang individu tergerak untuk memilih jalan/alur yang telah dirancang oleh sang arsitek tanpa harus diberitahu signage.
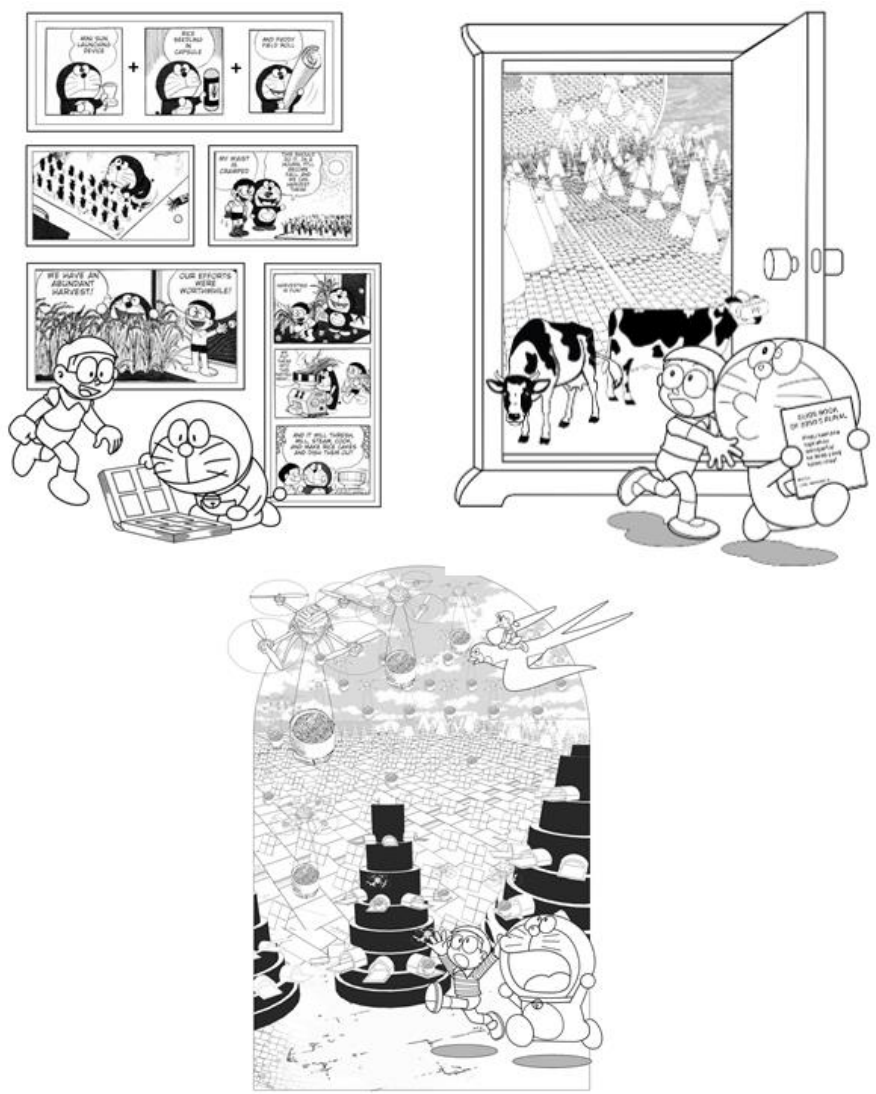

Gambar 1. Drawing as Hypothesis menggunakan narasi Doraemon Sumber: Penulis, 2020

Proyek ini meminjam sebuah narasi dari cerita Doraemon karena dinilai memiliki suatu koneksi dengan narasi yang ada di Desa Singosari. Dalam hal ini penulis menerapkan arsitektur naratif dimulai dari menyusun konsep hingga sebagai alat komunikasi berupa drawing as hypothesis, di mana menampilkan beberapa gambar sebagai ide desain yang nantinya akan dikembangkan lebih lanjut. 


\section{DISKUSI DAN HASIL PERANCANGAN}

\section{Analisis Lokasi}

Kabupaten Boyolali terletak di dekat Kota Solo dan letaknya tepat di sebelah utara Gunung Merapi. Salah satu keunikan yang dimiliki Boyolali adalah julukan yang melekat yaitu New Zealand Van Java, karena Boyolali terkenal dengan peternakan sapi perahnya dan daerah penghasil susu terbesar di Jawa Tengah. Selain julukan New Zealand Van Java, Boyolali juga dijuluki sebagai Kota Susu. Untuk mempertegas citra sebagai Kota Susu, Boyolali membangun beberapa ikon kota yang tidak jauh dari sapid an susu. Contohnya seperti Monumen Susu Murni yang menggantikan monument tugu jam, gedung Lembu Suro yang berupa sapi raksasa yang meringkuk di pusat pemerintahan Boyolali. Terhitung ada 22 kecamatan yang ada di Boyolali, salah satu kecamatan yang terkenal dengan peternakan sapi perahnya adalah Kecamatan Mojosongo. Bedasarkan riset yang dilakukan penulis melalui beberapa literatur, data kecamatan dari website pemerintah, dan wawancara kepada masyarakat yang ada di Kecamatan Mojosongo, merupakan salah satu daerah yang potensial karena area ini mendukung untuk tersedianya pakan hijauan dan cocok untuk dilakukan pemeliharaan sapi perah dan potensi perkebunannya.

\section{Desa Singosari}

Desa Singosari, Kecamatan Mojosongo merupakan wilayah Kabupaten Boyolali. Sebagian besar warga Desa Singosari menggantungkan hidup dari perternakan. Perternakan sapi menjadi menjadi komoditas utama di desa tersebut. Ada sekitar 90\% warga bermata pencaharian sebagai perternak sapi perah. Pada umumnya setiap penduduk di Kecamatan Mojosongo memelihara 3-4 ekor sapi perah, namun ada beberapa peternak menengah yang memelihara 4-7 ekor sapi perah.

Dalam pemilihan tapak di Desa Singosari, terdapat beberapa pertimbangan yang perlu diperhatikan, meliputi:

a. Permukiman penduduk yang mayoritas memiliki pekerjaan sebagai peternak kecil dan petani kebun.

b. Masyarakat desa setidaknya sudah ter-expose dengan jaringan internet dan memiliki ponsel.

c. Lokasi tapak dekat dengan potensi yang telah disebutkan diatas (peternak besar dan peternak kecil) dan SDM (sekolah).

d. Akses menuju tapak melalui jalan yang memiliki lebar $\pm 6 \mathrm{~m}$ untuk memudahkan aksesibilitas/pencapaian menuju tapak.
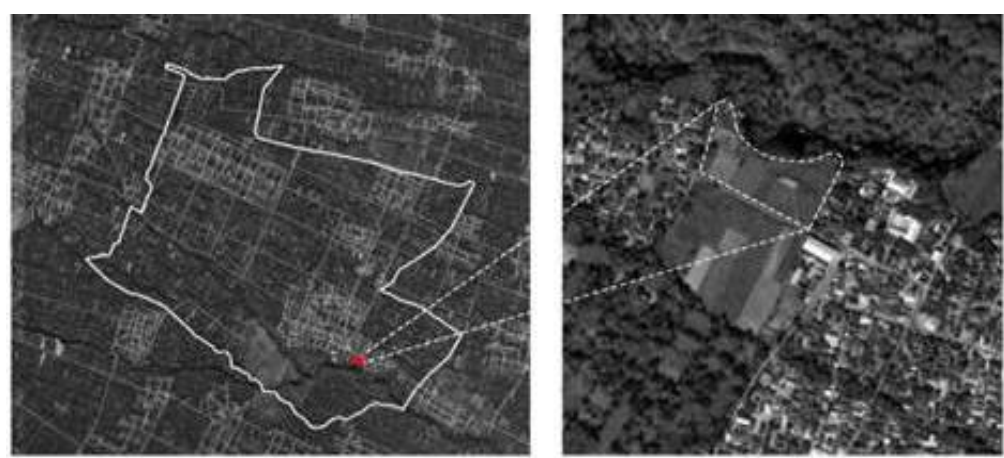

Gambar 2. (Kiri ke Kanan) Desa Singosari, Tapak Terpilih Sumber: Penulis, 2020

\section{Analisis Program}

Setelah melakukan analisis dan menentukan lokasi terpilih selanjutnya adalah eksplorasi potensi dan masalah yang ada disekitar tapak. Hal ini bertujuan untuk melihat gambaran besar 
sehingga dapat di susun suatu strategi. Program awal merupakan hasil sintesis dari berbagai potensi dan masalah yang ada di Desa Singosari lalu megerucut ke dalam program inkubator sebagai program untuk penyerapan tenaga kerja, peningkatan dan pemberdauaan talenta digital di teknologi yang nantinya diharapkan akan memicu usaha/lapangan pekerjaan baru dan inovasi teknologi di bidang pertanian. Adanya program inkubator dapat memicu suatu ekosistem baru dimana kaum muda desa dapat menginisiasi suatu hal yang diangkat dari lokalitas areanya, contohnya di Desa Singosari terkenal dengan penghasil susu sapi dan perkebunan sehingga hal ini dapat menjadi peluang baru untuk mereka bereksperimen sekaligus berinovasi di masa depan.

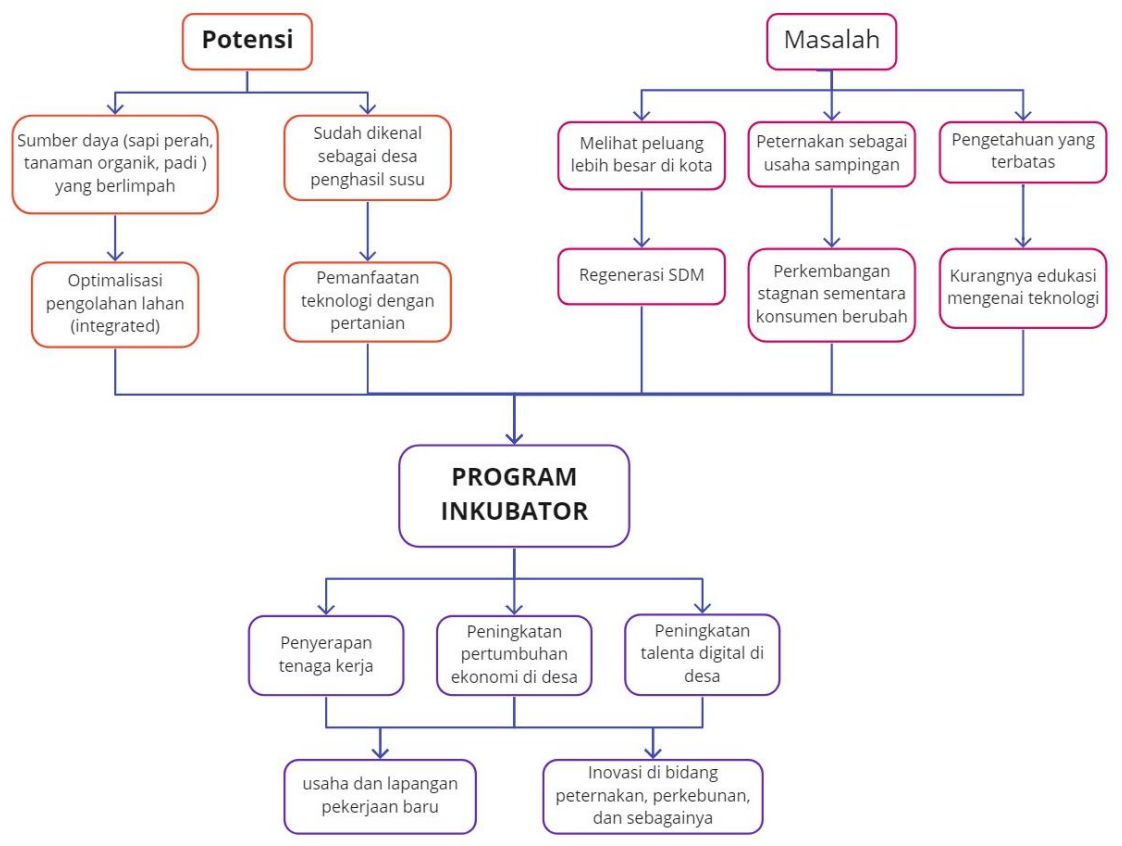

Gambar 3. Diagram Menuju Program

Sumber: Penulis, 2020

\section{Analisis Konsep}

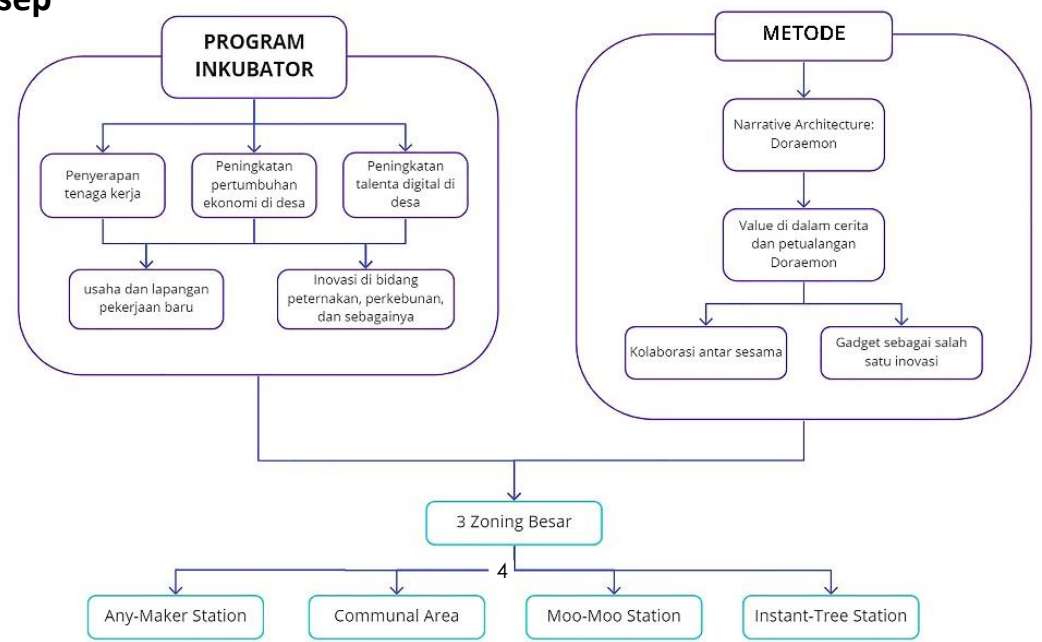

Gambar 4. Program dan Metode

Sumber: Penulis, 2020

Program Inkubator yang ada dianalisis dan dieksplorasi kelokalannya baik dari segi peternakan maupun perkebunan, sebagai mata pencaharian utama masyarakat di Desa Singosari. Dapat 
dilihat terdapat 4 tipe aktivitas yang dapat di upgrade menggunakan gadget Doraemon yang sesuai dengan fungsinya masing-masing. Irisan ini menghasilkan 4 zoning besar yang terdiri dari:

\section{a. Any-Maker Station}

Merupakan zona yang ditujukan untuk kegiatan belajar mengajar dan sebagai sumber ilmu. Pada zona ini terdapat secondary entrance, learning studio, e-library, staff area, dan student toilet.

b. Communal Area

Mengangkat lokalitas Desa Singosari di mana keseharian masyarakatnya rutin mengadakan acara tertentu setiap minggu dan terdapat festival lebaran sapi. Zona ini mempunyai tujuan sebagai wadah tempat bertukar ide, pelatihan, sekaligus wadah yang akan membentuk ekosistem dari program inkubator. Pelatihan ini bisa bermacam-macam, mulai dari pembinaan terhadam UMKM, pelatihan teknologi dan elektronik, pelatihan skill penunjang yang lain. Pada zona ini terdapat social pockets, workshop area, meeting pods, storage, dan public toilet.

c. Moo-Moo Station

Salah satu potensi Desa Singosari terletak pada produksi susu, namun peternakan saat ini masih cenderung menggunakan cara tradisional. Dengan adanya zona ini dapat meningkatkan produktivitas proses pemerahan susu menjadi lebih cepat dan efisien dengan menggunakan teknologi rotary milking parlour langsung terhubung dengan moo-moo production (tempat penyimpanan susu). Pada zona ini juga terdapat pop up store yang bertujuan sebagai ruang tempat berjualan UMKM Desa Singosari.

d. Instant Tree Station

Potensi kedua Desa Singosari dimana perkebunan menjadi salah satu andalan setelah susu. Menggunakan teknologi aeroponic garden yang tidak memerlukan tanah, mengurangi debit air yang digunakan untuk menyiram tanaman, dan hasil yang lebih premium.

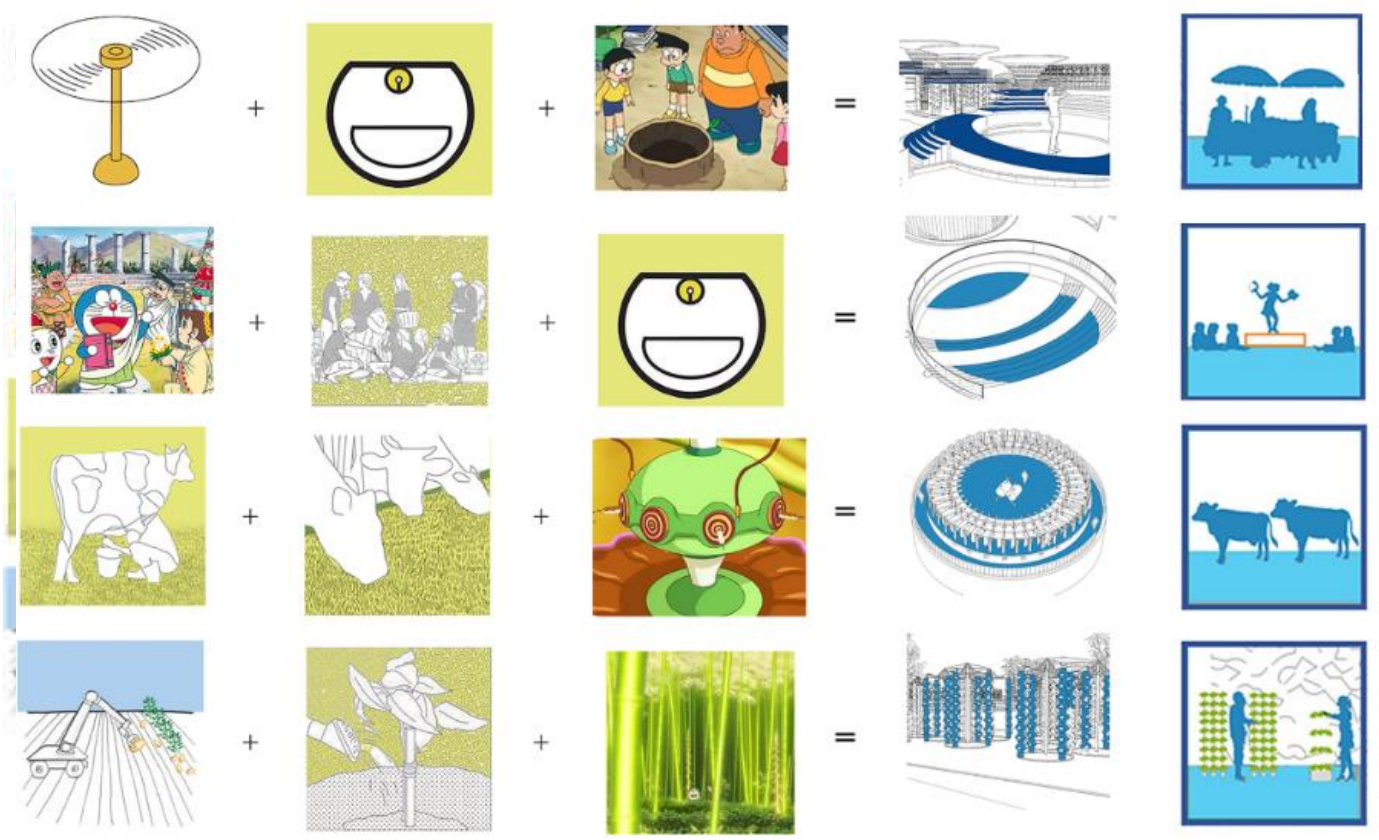

Gambar 5. Lokalitas + Elemen dari Narasi Doraemon Sumber: Penulis, 2020 
Seperti pada gambar 5 pada baris pertama menunjukan aktivitas memerah sapi, memberi makan sapi, dan gadget doraemon dapat menghasilkan suatu teknologi yang bernama rotary milking parlour dimana hamper 40 sapi dapat diperah secara bersamaan menggunakan mesin dan sapi-sapi tersebut dapat sekaligus diberi makan. Baris kedua menunjukan bahwa teknologi yang sudah ada (robot harvesting) jika di upgrade dengan sebuah teknologi yang bernama aeroponic (tidak menggunakan media tanam berupa tanah dan disiram dengan air secukupnya/water mist). Baris ketiga menunjukan manifestasi baling-baling bamboo dan kantong ajaib menjadi bentuk massa (lingkaran) yang menggunakan atap berstruktur bambu, selain itu atap ini menggunakan prinsip sustainable dengan adanya rain-water harvesting. Sedangkan baris ke empat memperlihatkan bagaimana sebuah komunitas dapat mengekspresikan pertunjukan budaya mereka di dalam 'kantong-kantong' (social pockets) dengan ukuran yang berbeda-beda, disesuaikan dengan kapasitas penggunanya.

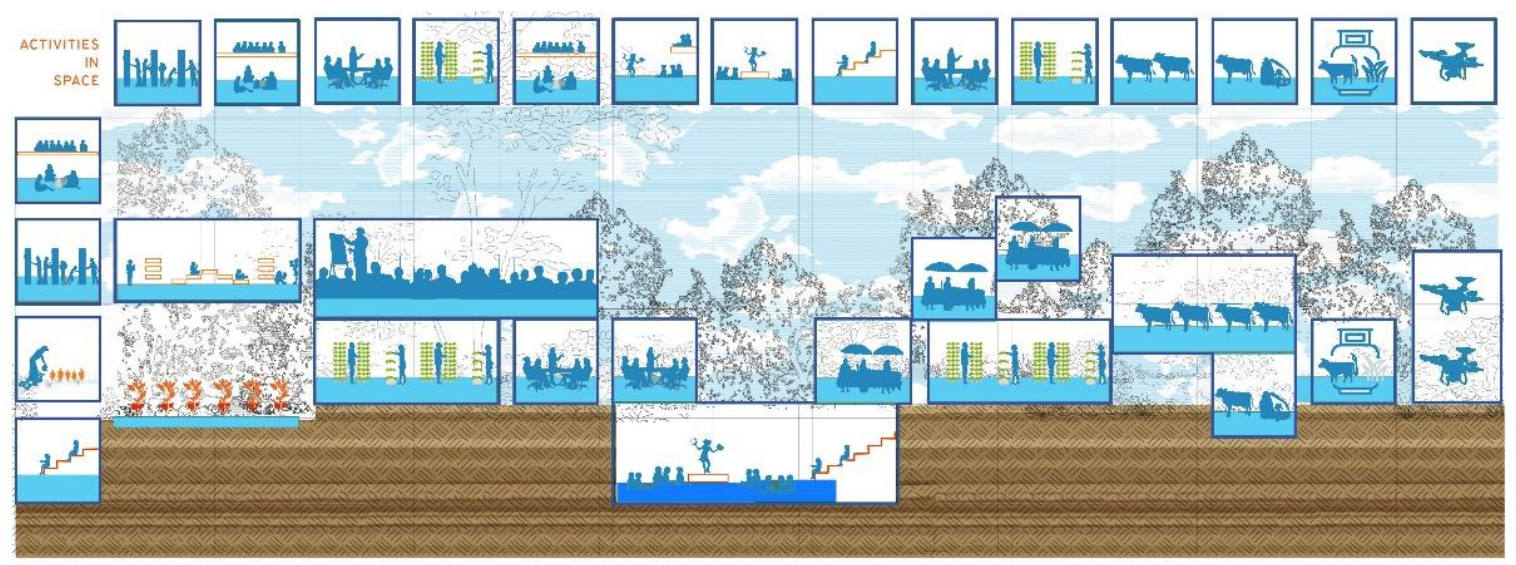

Gambar 6. Diagram Distribusi Aktivitas dalam Potongan Konseptual Sumber: Penulis, 2020

Aktivitas yang terbentuk dari gambar 5 kemudian di kembangkan ke dalam diagram sehingga kita dapet melihat distribusi aktivitas yang ada dalam proyek ini. Terlebih lagi diagram ini berupa potongan konseptual untuk memperlihatkan kemungkinan terbentuknya ruang-ruang baru karena crossing aktivitas yang berbeda dan permainan leveling yang bervariasi mengikuti aktivitasnya.

\section{Pembentukan Massa}

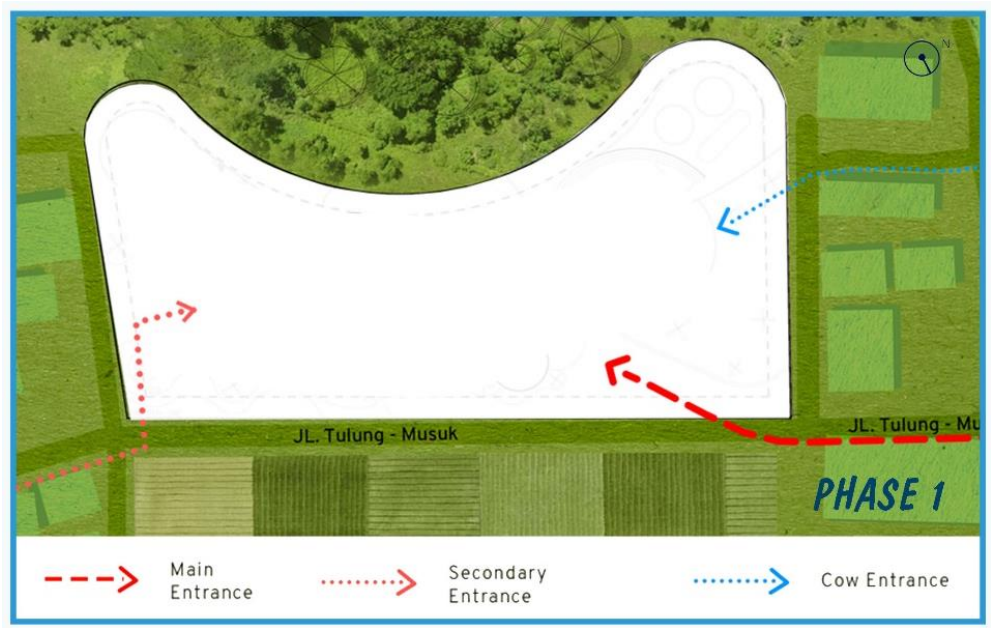

Gambar 7. Fase 1: Aksesibilitas

Sumber: Penulis, 2020 
Proses pembentukan massa diawali dengan memperhatikan dasar peraturan meskipun peraturan di desa tidak detail seperti di kota, penulis tetap mengikuti dasar yang ada seperti lebar GSB menggunakan parameter $1 / 2$ dari lebar jalan utama.

Kemudian proses desain terbagi menjadi 3 fase. Fase pertama, menentukan titik pintu masuk berdasarkan aksesibilitas dan konteks tapak dimana main entrance menghadap jalan utama, cow entrance menghadap jalan dari peternak besar, dan secondary entrance berdekatan dengan pemukiman penduduk seperti pada gambar 7 .

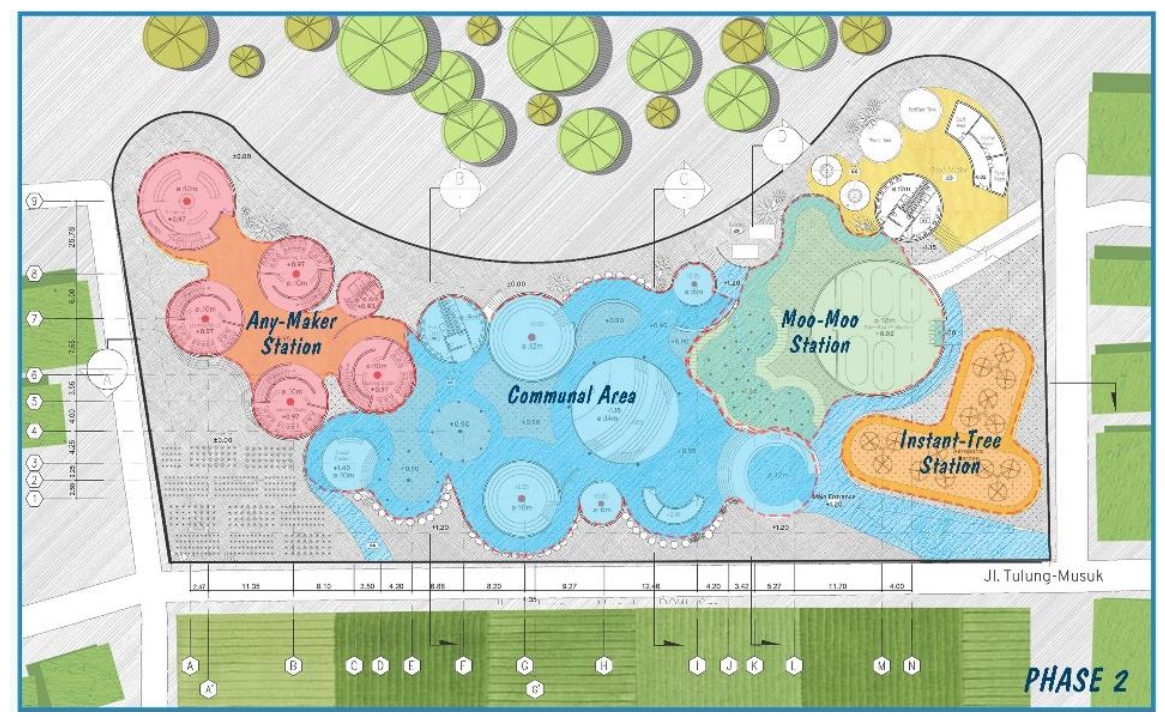

Gambar 8. Fase 2: Pembagian Zoning

Sumber: Penulis, 2020

Selain itu, pertimbangan titik pintu masuk juga disesuaikan dengan penempatan 4 zoning besar sesuai dengan fungsinya masing-masing dan arsitektur naratif yang berdasarkan elemen yang ada dalam cerita Doraemon (dijelaskan lebih lanjut pada gambar 10).
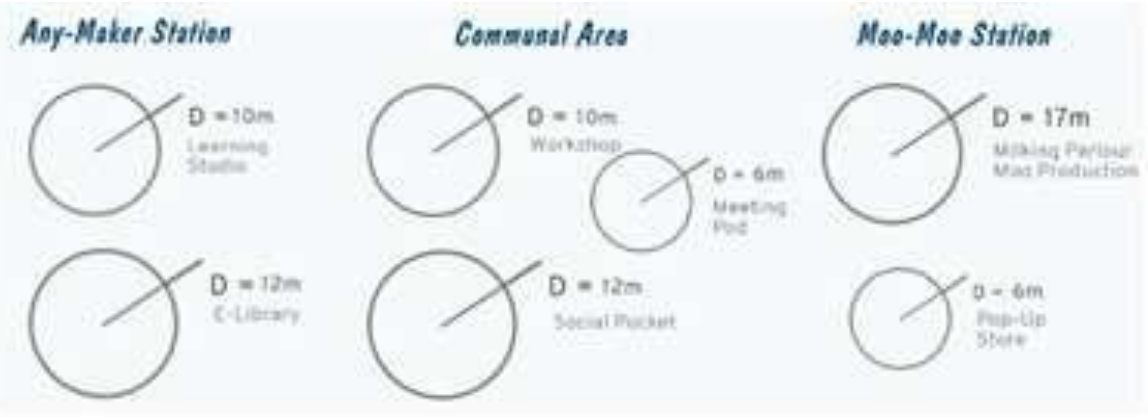

Gambar 9. Ukuran Ruang Berdasarkan Kapasitas \& Fungsi Sumber: Penulis, 2020

Setelah diputuskan letak akses masuk, 4 zona besar mulai disusun ke dalam tapak yang kemudian secara pararel disesuaikan ukuran, bentuk, dan leveling-nya. Bentuk ruang yang bulat terinspirasi dari bentuk kantong ajaib Doraemon dan fungsi pada ruang-ruang tersebut di analogikan sebagai berbagai macam gadget yang ada di dalam kantong (masing-masing memiliki fungsi dan keunikan). Masing-masing ruang memiliki ukuran yang berbeda-beda hal ini disebabkan setiap ruang memiliki fungsi dan kapasitas yang berbeda, sebagai contoh learning area memiliki diameter $10 \mathrm{~m}$ karena berfungsi sebagai ruang belajar yang berkapasitas 25-30 orang sedangkan salah satu social pocket memiliki diameter $12 \mathrm{~m}$ dan level yang berbeda 
(berbentuk seperti sunken amphiteatre berkapasitas 50-80 orang) karena berfungsi sebagai tempat berekspresi dan berkumpul (jika ada acara tidak harus dilaksanakan di balai atau di suatu ruang serbaguna tetapi bisa menggunakan ruang ini). Sunken amphiteatre ini dibuat memendam kebawah sekaligus meredam bising dari lingkungan sekitar. Social pocket terdiri dari 2 tipe yaitu sunken amphitheatre (diturunkan) dan social pocket yang sifatnya peningkatan level ke atas.
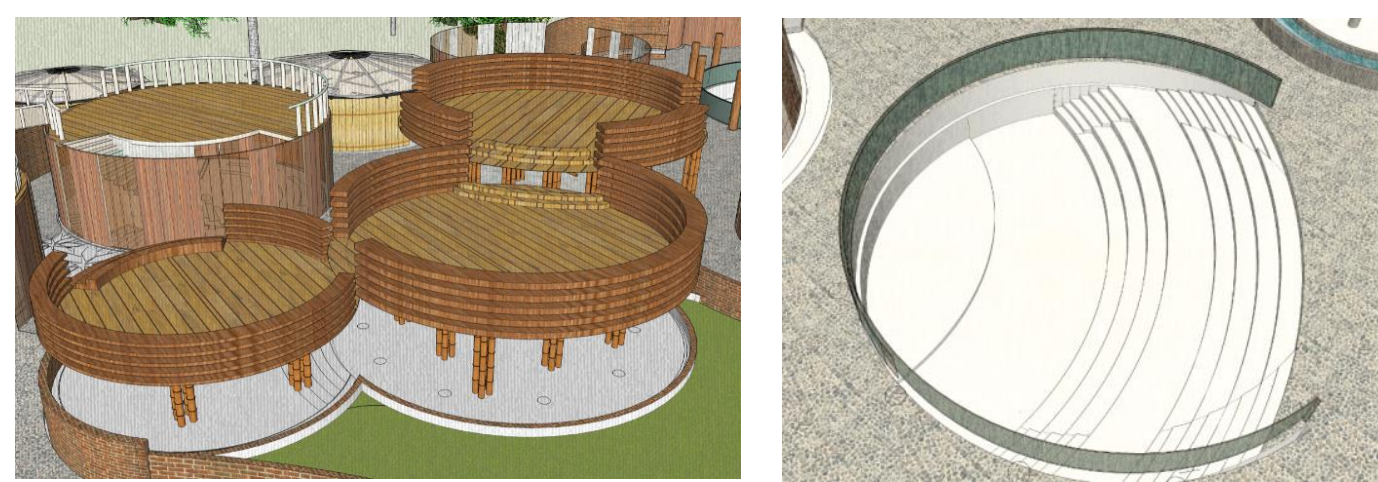

Gambar 10. Social pockets, sunken amphitheatre Sumber: Penulis, 2020

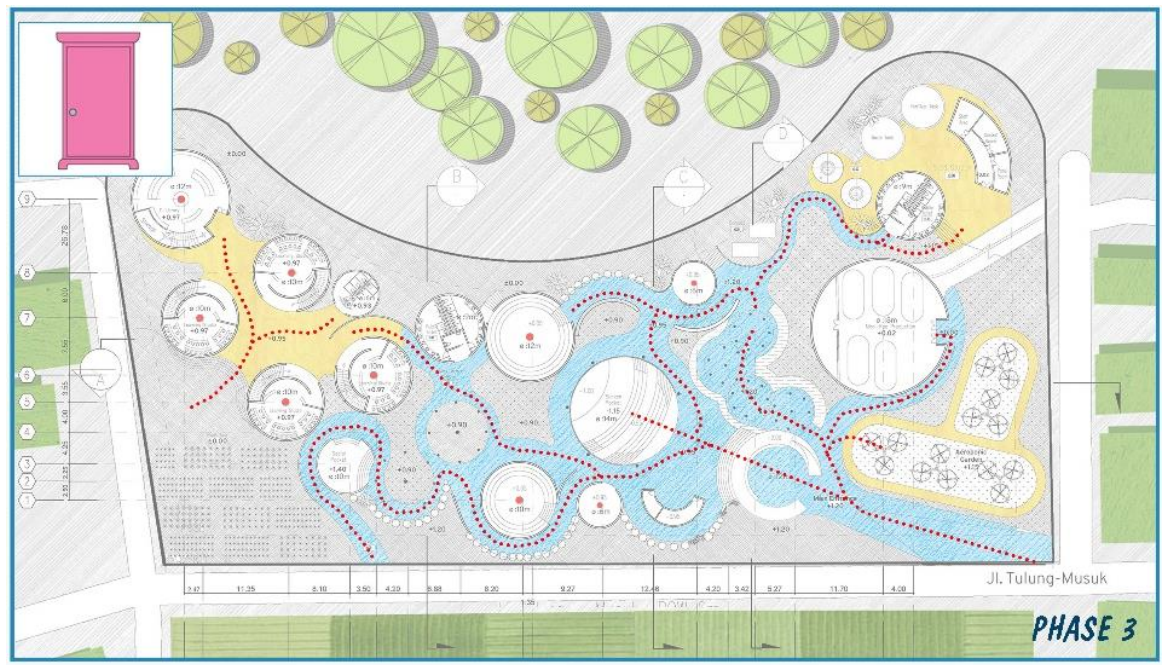

Gambar 11. Fase 3: Sirkulasi di dalam Tapak Sumber: Penulis, 2020

Pada fase 3, sudah terlihat bentuk massa yang di dasari dari salah satu gadget Doraemon yaitu pintu kemana saja, dari sirkulasi dapat terlihat terdapat pintu masuk utama yang setelahnya terbagi menjadi beberapa alur sirkulasi. Sirkulasi ini secara tidak langsung di buat untuk menganalogikan seolah-olah sebuah pintu, ketika berjalan mengikuti alur terdapat pilihan ingin berbelok ke kiri/kanan/lurus. Setiap pilihan yang diambil baik kiri/kanan/lurus menuju ruang dengan fungsi dan level yang berbeda-beda, mencoba membuat suasana yang berbeda dan kepekaan seseorang terhadap ruang. Levelling pada proyek ini memiliki ketinggian maximum $7 \mathrm{~m}$, hal ini berkaitan dengan kontekstualitas dengan lingkungan sekitar di mana perumahan warga serta sekolah yang ada memiliki ketinggian sekitar $3 \mathrm{~m}-7 \mathrm{~m}$. Selain itu proyek ini juga menggunakan material lokal, salah satunya bambu. Bambu digunakan sebagai penopang atap dari setiap ruang, bambu juga sebagai analogi dari gadget doraemon yang bernama baling-baling bambu. 


\section{KESIMPULAN DAN SARAN}

\section{Kesimpulan}

Proyek yang dirancang dengan ide mengangkat narasi Doraemon yang secara bersamaan mengabungkannya dengan program inkubator di Desa Singosari dapat mewadahi potensi sumber daya manusia, terutama kaum muda, yang ada disana untuk mempersiapkan mereka dengan berbagai macam program pemberdayaan dan pelatihan. Sehingga mereka juga mendapatkan kesempatan yang sama untuk belajar dan beradaptasi dengan kemajuan dan trend teknologi yang sedang berkembang. Narasi Doraemon diangkat dengan mengangkat value dan elemen yang ada di dalam cerita petualangan Doraemon, seperti baling-baling bambu yang di analogikan sebagai naungan sekaligus rain-water harvesting berbentuk bulat dengan material bambu. Melalui proyek ini, tercermin betapa besarnya cita-cita kaum muda di desa yang menginginkan masa depan bagi desa mereka masing-masing. Dimana semangat gotong-royong yang turun temurun menjadi bekal utama untuk berkolaborasi tertuang dalam ruang-ruang sosial yang ada di dalam proyek. Proyek ini adalah titik balik dan awal dimana kaum muda menjadi aktor utama di desa mereka karena sejatinya mereka juga berhak untuk mewujudkan cita-cita mereka.

\section{Saran}

Selama ini kita cenderung memandang desa sebelah mata, namun tidak kali ini. Saat ini sudah banyak sekali usaha-usaha lokal yang berasal dari pedesaan sudah berhasil menembus pasar nasional-bahkan ada yang internasional. Itu semua tidak terlepas dari andil masyarakat yang mau belajar dan komunitas yang ada memfasilitasi. Alangkah indahnya jika kaum muda (tidak hanya di desa melainkan seluruh kaum muda di perkotaan juga), sebagai penerus bangsa, dapat saling bertukar ilmu dan berkolaborasi untuk memajukan desa-desa di Indonesia. Program Inkubator bukanlah hal baru di dunia start-up dan bisnis, tak jarang melalui program ini telah melahirkan usaha-usaha yang inovatif dan membantu banyak orang. Pertanyaannya, mengapa kita-sebagai arsitek-tidak mencoba untuk mengadopsi program tersebut untuk di integrasikan ke dalam proyek? Padahal kita membangun suatu bangunan untuk manusia bukan? Untuk membangun komunitas yang berkelanjutan bukan? Lantas, mengapa seolah kita seringkali berfokus pada ide di seputar arsitektur saja dan tidak berfokus pada keberlanjutan program yang ada. Padahal bangunan yang kita bangun akan ada untuk beberapa puluh tahun mendatang dan mereka, yang menghuni, butuh diberdayakan untuk berkembang. Hal inilah yang menciptakan sebuah peluang di mana kita dapat berkolaborasi dengan berbagai industri untuk menciptakan sebuah ekosistem yang berkelanjutan.

\section{REFERENSI}

Bappenas. (2017). Bonus Demografi 2030-2040: Strategi Indonesia Terkait Ketenagakerjaan dan Pendidikan. Jakarta.

Jamaludin, A.N. (2015). Sosiologi Pedesaan. Bandung: CV. Pustaka Setia.

Kasali, R. (2018). The Great Shifting. Jakarta: Gramedia.

Kementrian Riset, Teknologi dan Pendidikan Tinggi. (2017). Buku Panduan Inkubasi Bisnis Teknologi.

Heideger, M. (1962). Being and Time. New York: Harper.

Norberg-Schulz, C. (1985). The Concept of Dwelling: On the way to figurative architecture. New York: Rizzoli.

Psarra, S. (2009). Architecture amd Narrative: The Formation of Space and Cultural Meaning. London: Routledge.

Tisskink, F. E. (2016). Narrative-drive design: Roles of narratives for designing the built environment. Delft: TU Delft. 
S. Raucek dan L. Warren. (1984). Sociology an Introduction. Terj. Sahat Simamora. Jakarta: Bina Aksara, 102-121.

Solomon, R. (2020, February). Rem Koolhas and AMO Explore Radical Change in the World's Nonurban Territories in the Guggenheim Exhibition Countryside, The Future.

World Economic Forum. (2016). The Future of Jobs. 